\title{
Identity (self-)deconstruction in Chinese police's civil conflict mediation
}

\author{
Wenjing Feng and Xinren Chen \\ Nanjing University
}

\begin{abstract}
While recent pragmatic research on identity in discourse mainly focuses on ubiquitous construction of one's own or others' identity, inadequate attention has been directed to the frequently occurring deconstruction of selfconstructed and other-assigned identities. Drawing on transcripts of recordings of 19 Chinese police officer-mediated interactions, this study examines what, how and why self-constructed and other-assigned identities of police officers are deconstructed. Qualitative analysis of the data shows that Chinese police officers' self-constructed non-institutional identities were often deconstructed by disputants via negating their contextual appropriateness or their social or institutional rightness, whereas police officers also often deconstructed the institutional identities assigned to them by the disputants via negating the validity of the assigned institutional identity or the institutional relationship. It is argued that the cause of this identity deconstruction phenomenon is rooted in police officers' identity dilemma arising from social changes regarding police work in China.
\end{abstract}

Keywords: institutional discourse, identity, pragmatic identity, identity deconstruction, mediation, Chinese police mediation

\section{Introduction}

The notion of identity has increasingly been examined in the field of linguistics and communication studies (Chen and Chen 2020). Related research has shifted from essentialism (which sees identity as fixed and static) to constructionist (which assumes that identity is fluid, dynamic, discursively and locally achieved) (Antaki and Widdicombe 1998), relationally produced and interactionally interpreted (Bucholtz and Hall 2005; de Fina et al. 2006; Locher et al. 2015). Some scholars try to balance between the two views. For example, Tracy $(2002,21)$ defines identity as follows: 
Identities, then, are best thought of as stable features of persons that exist prior to any particular situation and as dynamic and situated accomplishments, enacted through talk, changing from one occasion to the next.

To differentiate the two aspects of identity in Tracy's definition above, Chen $(2013,2014,2018,2020)$ proposes the concept of "pragmatic identity" for the latter, which refers to the identity/identities people choose to construct discursively in the process of interaction to meet their communicative need or goal. Unlike pre-existing social identities, identity in the pragmatic sense is discursively constructed in interaction on the basis of the identity attributes people already possess, or falsely invented ad hoc.

Pragmatically, identity, which is utterance-bound and contextually chosen, is dynamic and subject to deliberate operation. Communicators "can construct and deconstruct, project and hide, and affirm and negate self- and other-identity in interaction for a wide range of extralinguistic purposes" (Li and Ran 2016, 47). To date, while there have been numerous studies that focus on ubiquitous construction of identities, there has been less attention paid to the frequently occurring deconstruction of identities - the process of negating or denying an identity that has been selected and discursively constructed by oneself or some other participant(s) (cf. Dobs 2014; Donaghue 2018; Locher 2011), a research gap to be filled in this study.

Specifically, we will explore how identity deconstruction takes place in Chinese police mediation contexts. Mediation is "the process in which a neutral third party helps parties involved in a dispute fashion their own resolution to the dispute" (Cooper 2001, 281). While many existing studies focus on mediators' neutrality (Garcia 2012; Heisterkamp 2006; Jacobs 2002; Marinova 2007) and relational management (Morasso 2011; Stokoe and Sikveland 2016) in Western mediation contexts, "little is known about the mechanisms of Chinese mediation" (Ran and Zhao 2018, 186), particularly police mediation in civil conflict contexts. In China, mediation has become an important tool for police officers in "improving relations with citizens and helping to create and sustain more peaceful communities" (Volpe 2014, 93). Although it has been a preferred dispute resolution method throughout Chinese history (Wall and Blum 1991), it was not until 2006 that police mediation was written into law and it is until recently that police mediation has become a major way to solve civil conflicts in China. According to one of the co-authors' ethnographic study, about $52 \%$ of cases reported to the police station are civil conflicts without violating any law, among which $74 \%$ are solved successfully by police mediation.

Drawing on data (transcripts of recordings of 19 Chinese police officermediated interactions involving 14 Chinese police officers and 38 citizens) from 
the co-author's one-month participation in and observation of the mediation work process at a Chinese police station, this study seeks to examine how various self-constructed and other-assigned identities of Chinese police officers are deconstructed, and why this dynamic process of identity deconstruction may have occurred.

\section{Literature review}

\subsection{Previous research on identity deconstruction}

Most previous studies involving the use of "identity deconstruction" as a key word are based on Derrida's philosophy of Deconstructionism/ Post-structuralism/ Post-modernism as opposed to the essentialist view of identity, including gender identity (Poovey 1988; Gamson 1995), regional identity (Klooster 2002), political identity (D'Cruz 2008), racial identity (Wagner et al. 2009), etc. They focus on how social changes give rise to the need to replace the static essentialist concept of identity with a dynamic constructionist one. Although none of them has explored identity deconstruction from a pragmatic point of view, they do feature some aspects relevant to identity deconstruction in our sense: identity negotiation, denial and contestation.

Identity negotiation is an "agentic identity work carried out in response to contextual demands" (Deaux and Ethier 1998, 301). Related strategies include identity negation and identity enhancement (ibid.). Claimed identities can be either verified or challenged and contested (Donaghue 2015, 39).

To date, there have been scattered discussions on identity deconstruction. For example, Li and Ran (2016) and Li, et al. (2018) studied how one constructs one's professional identity by means of deconstructing other' s identity in Chinese televised debating discourses by challenging or negating other' $s$ attributes such as professional role, competence and ethics. Schnurr and Zayt (2011) explored how the new role of a team leader is often resisted and challenged by other team members by questioning her authority and decisions or undermining her display of power and authority (Donaghue 2015, 39). Mullany (2008) investigated the impoliteness strategies used in meetings in a UK manufacturing company to challenge a manager's power and claimed identity. Donaghue (2018) analyzed different (polite or impolite) relational work two advisers did in negating the same professional identity a teacher claims for himself in the post teaching review. Dobs (2014) investigated how students used impoliteness strategies like scorn to reject an unwanted discourse identity ascribed to them by their interlocutors. Locher (2011) examined how interactants in an online forum used face aggra- 
vating behaviour like sarcasm to reject unwanted ascribed identities. While these studies are enlightening to our discussion here, many ways in which identities are challenged, negated or deconstructed remain unexplored. In addition, various factors in both the immediate and the wider social contexts of interaction/ communication that may also exert great effects on the process of identity deconstruction have not been adequately explored.

\subsection{Previous research on Chinese mediation}

Mediation in China has a long history and differs significantly from that in the western contexts (Wall and Blum 1991). To date, studies on Chinese mediation are mainly about mediation practice in courtrooms ( $\mathrm{Li}$ and Song 2014; Jiang 2016; Ke 2017), communities (Wall and Blum 1991; Tong 2013) or TV programs (Ran and Zhao 2018; $\mathrm{Xu} 2019$ ). In these contexts, while neutrality is not a concern for mediators in most of the cases, major goals are to eliminate the dispute and keep the anger down, and both mediators and citizens feel the mediator's decision as to who is correct is even more important than the resolution of the dispute (Wall and Blum 1991, 10; Deng, et al. 2013, 9).

Police mediation is one special branch of mediation, for "it represents a broader range of activities, including brokering and petitioning as well as arbitration, a condition in which the third party does have power" (Buerger et al. 1999, 129). Studies on police mediation have a long history in Western countries (see Bercal 1970; Black 1980; Cooper 2001; Volpe 2014). Since a new law in 2006 in China established mediation as police officers' legal obligation, police mediation has become one of major ways to solve civil conflicts. However, related research is limited. While previous research mainly takes legal or administrative perspectives (Gao 2008; Wang 2014; Shen 2015), discussion on Chinese police mediation discourse from pragmatic perspective is scarce.

To sum up, while there have been rich studies on the construction of institutional identities as well as limited research on the deconstruction of professional identity, little attention has been paid to the deconstruction of various identities especially the non-institutional identities in discourses in institutional settings, particularly the Chinese police mediation contexts. This study focuses on the identity deconstruction phenomenon occurring in the process of the strategic use of non-existing identities such as family members, acquaintances, friends, etc. by Chinese police officers in civil conflict mediation interactions. 


\section{Methodology}

\subsection{Research questions}

This study addresses the following research questions:

1. What chosen identities of Chinese police officers are then deconstructed in the course of mediation?

2. How are the chosen identities of Chinese police officers deconstructed?

3. Why does the deconstruction occur?

\subsection{Data collection}

The present study collected naturally occurring mediation discourse involving an interpersonal dispute in which Chinese police officers served as mediators, where the dispute did not provide the officers with adequate grounds to arrest or accuse any disputing party for law violation. The successful resolution of conflicts in mediation was marked by an agreement of reconciliation in the form of a paper contract signed between the two parties of disputes.

The data used in this study come from the ethnographic study conducted by a co-author from June 14th to July 2oth in 2018 by participating in and observing of the police officers' mediation work in a police station in Anhui Province, China. The data are the transcripts of 13 -hour-long audio recordings of 19 Chinese police officer-mediated interactions involving 14 Chinese police officers, 38 citizens of one city in the province, all of whom consented to have their mediation process recorded for research purposes. According to the same co-author's survey by questionnaires, most of the police officers had never received any special training on mediation. The only guide they had obtained was one handbook with previous successful mediation cases.

The data were selected primarily because they were representative of the Chinese civil conflict mediation discourse with police officers as mediators. In terms of interactional dynamics, this mediation type included one or two police officers, two parties within an offender-offendee relationship, each with one or more people from different social classes, such as farmers, company manager, city citizens, and homeless people. These disputants were in multiple relationships from closed family members to total strangers to each other. The issues concerned were closely related to everyday life, covering trifles, land problem, debt problem, etc., providing a vivid snapshot for the general picture of Chinese people's civil conflicts. 


\subsection{Data analysis}

The mediation conversations (to protect the anonymity of the participants, the names of the participants were replaced with English letters and all other information that could identify them was removed) were closely examined for instances of deconstruction of the police officers' identities.

As the first step, we looked for those parts of the mediation discourses which involved overtly or implicitly negating an identity that had been chosen by the police officer(s) or the disputant(s). On the basis of the indexicality principle (Bucholtz and Hall 2005), we depended on the following discursive strategies (Chen 2013, 2018; Tracy 2002) to locate the instances of identity deconstruction in our data (1) the overt mention of a different identity category or label; (2) emphasizing a different kind of category-bound activity or obligation (Sacks 1972); (3) negating the validity of the speech act used to construct the identity; (4) claiming a different kind of identity relationship. While these discursive means helped us identify the instances of identity deconstruction, our analysis focuses on the immediate contextual and social rationales, based on which the various identities of Chinese police officers were deconstructed.

Take the following extract from Chinese civil conflict mediation at one police station for example:

\section{Extract 1.}

(Context: A was a villager falling in dispute with a worker B who repaired the road in front of his house. A stayed in hospital for four days and wanted B to pay for it, but after investigation, the police found that A was not hurt by B. A was very excited. Here, $\mathrm{P}$ stands for the police officer who conducts mediation for A and B.)

o1 P：陈师傅，我问你，你可尊重我？我可尊重你？从你一进门口，我可 尊重你?

$02 \mathrm{~A}$ ：你是人民的保安! 我是无知的群众，你是为我们服务的！我们的话 语是不一样的!

03 P：我们是不是应该互相尊重?

O4 A：互相尊重只是一个说法!

o1 P: Chen Shifu, let me ask you, do you respect me? And do I respect you? From the moment you came into this room, do I respect you?

02 A: You are the people's security guard, and I'm one of the innocent and ignorant people and you are here to serve us! So our discourses are different!

o3 P: We should respect each other, shouldn't we?

04 A: Mutual respect is just a kind of saying! 
In this extract, in face of the A's rude manners, $\mathrm{P}$ constructed the identity of an ordinary individual who deserved equal polite treatment from A by addressing him with his family name Chen 陈 followed by the address term Shifu 师傅, which means 'master' or an elderly person who imparts skills (Wen 2018) and nowadays is used commonly in everyday life talk to show respect in Chinese (o1). He also used two rhetorical questions (Ni ke zunzhong wo? Wo ke zunzhong ni? 你 可尊重我? 我可尊重你? ) (o1), serving as an indirect criticism of A's rudeness and a request of mutual respect from A. But A deconstructed this equal identity by overtly mentioning the identity categories labels (Bucholtz and Hall 2005) 'the people's security guard' (renmin de baoan 人民的保安) and 'the innocent and ignorant people' (wuzhi de qunzhong 无知的群众) and the category-bound activity or obligation (Sacks 1972) of police officers 'to serve us' (wei women fuwu 为我 们服务) (02), thus positioning $\mathrm{P}$ in his institutional identity which A assumed as unequal and can serve as a rationale for his impoliteness to be considered as "reasonable hostility", that is, "emotionally marked criticism of the past and future actions of public persons" (Tracy 2008, 169). From a target's perspective, reasonable hostility will almost always be seen as rude and unfairly attacking, but for others, criticisms are regarded as morally warranted (ibid.), and in police mediation A's rude manner seemed to be warranted by the institutional setting, namely, the prescribed institutional identity and interpersonal relationship provide a rationale for A to negate the validity of the police officer's self-constructed identity of an ordinary individual who deserves equal politeness from A.

Two other researchers helped the authors categorize and identify the identity deconstruction cases in the data and the cases that could not be decided consistently by all the four of us were excluded.

As the next step, the isolated cases and relevant parts of the debating conversation in which these instances occurred were then transcribed according to $\mathrm{Du}$ Bois et al.s (1993) transcription conventions (see Table A1 in Appendix 1) due to its convenience to represent discourse features such as interactants' pitch and laughter, which are important signals or markers of implicit deconstruction of identity and its effects on interpersonal relationship.

In sum, five episodes were chosen for close analysis. Their detailed information is listed in Table 1. In the data analysis, we will present each excerpt in the following format: First, the situational context is provided, including the participants' social background and the conflict details; second, the excerpt is provided both in Chinese and in an English translation, with the parts of overt and implicit negation or deconstruction of police officers' identities being underlined. In each case, one or two police officers served as the mediator(s). They were all male, 25-45 years old, with 5-12 years of mediation experience. 
Table 1. Information about the data sources

Number of

\begin{tabular}{lllc} 
Conflict type & Disputants in mediation & characters \\
\hline 1 & $\begin{array}{l}\text { A villager and a road worker quarreled over a } \\
\text { pipe. }\end{array}$ & A villager and road worker & 1271 \\
2 & $\begin{array}{l}\text { A teenage boy smashed a neighbor's door to ask } \\
\text { her to pay back the money her husband owed to } \\
\text { the boy's father. }\end{array}$ & $\begin{array}{l}\text { The boy and his parents, } \\
\text { and their neighbor }\end{array}$ & 2682 \\
3 & $\begin{array}{l}\text { Two brothers quarreled over land problem. } \\
4\end{array}$ & $\begin{array}{l}\text { Two brothers in one village } \\
\text { living in one community quarreled over house } \\
\text { repair issue. }\end{array}$ & $\begin{array}{l}\text { A citizen and the manager } \\
\text { of the property } \\
\text { management company }\end{array}$ \\
$\begin{array}{l}\text { A passer-by tried to convince a homeless elderly } \\
\text { man to move to a safe place, because a typhoon } \\
\text { was coming. }\end{array}$ & $\begin{array}{l}\text { A homeless elderly man and } \\
\text { a passer-by }\end{array}$ & 2668 \\
\hline
\end{tabular}

In the next section, we will illustrate what, how and why (non-)institutional identities of police officers either constructed by themselves or assigned by the disputants were deconstructed.

\section{Results of the study}

A close examination of the data shows two types of identity deconstruction practice. One is that police officers' self-constructed identities were deconstructed by disputants via negating their contextual appropriateness, and the other is that police officers themselves deconstructed their other-assigned institutional identities via negating the institutional identity while at the same time claiming a noninstitutional identity.

\subsection{Disputants' deconstruction of police officers' self-constructed non- institutional identities}

Besides institutional identities, the police officers often constructed many noninstitutional identities; however, these contextually "deviant" identities were often overtly or implicitly deconstructed by the disputants in the following ways: (1) negating their appropriateness for the institutional setting, and (2) negating their social or institutional rightness. 


\subsubsection{By negating the appropriateness of the identities for the institutional setting}

No behavior is appropriate or inappropriate without taking into account the social context where it occurs, as put by van Dijk (2009, 50, 60):

Settings of social institutions are also associated with specific, socially conditioned, norms of language and discourse...The social definition of spaces and places has an influence on the properties of discourse that define their appropriateness with respect to the context.

In police mediation talk, the disputants sometimes simply deconstruct police officer's temporarily constructed identity by emphasizing the "institutionality" (Benwell and Stokoe 2006) of the communicative space or place. Consider Extract (2):

Extract 2.

(Context: A conflict between two neighbors living in one village: A's husband owes some money to B. B's son was very angry and smashed the front door of A one night. P refers to the police officer who conducts the mediation.)

O1 P: 你家小孩多大了?

O2 A：29。

O3 P: 在哪打工呢?

O4 A：在哪打工还要问么?

05 P：拉拉呱不行么?

06 A：拉什么？拉什么家常呱啊?拉家常呱也不来^这里呀！... ((省略))

O1 P: How old is your child?

O2 A: 29.

03 P: Where is he working?

$04 \mathrm{~A}:$ Is it necessary to ask about where he is working?

05 P: Can't we do a little casual chatting?

$06 \mathrm{~A}$ : What to chat about? What kind of casual chatting? People don't come^ ${ }^{\wedge}$ ere for chatting! ...

((Omitted))

In this extract, at the moment of mediation, the two disputing parties were very angry with each other due to the debt problem and the subsequently smashed door issue. $\mathrm{P}$ as the mediator tried to appease the tension by constructing an acquaintance identity with $\mathrm{A}$ (the one who called the police and wanted some remedy for her smashed door) by means of casually chatting about her family (o1, 03). Apparently, the chat was irrelevant to the dispute but only a kind of small talk. Such small talk, according to Malinowski (1923), may function "to achieve 
companionship" (Jin 2018, 32). But with extreme anger, A talked rudely to P to challenge the latter's temporarily constructed identity (Chen 2013, 2014, 2018) by asking a rhetorical question to negate the institutional rightness of the small talk: 'Is it necessary to ask about where he is working?' (Zai na dagong hai yao wen me? 在哪打工还要问么? ) (04). P responded with a rhetorical question 'Can't we do a little casual chatting?’ (Lala gua bu xing me? 拉拉呱不行么? ) (05), defending his adoption of a non-institutional identity based on the general Chinese social norm that strangers often do small talk to build an acquaintance-like relationship (Yuan 2011). But A's use of "hyperquestioning" (i.e. "repeated questioning within a turn leaving no opportunity for response") (Donaghue 2018, 111) (La shenme? La shenme jiachang gua a? 拉什么? 拉什么家常呱啊?) signaled her critical stance (o6). This confrontational question deconstructed P' s attempted acquaintance identity by negating its appropriateness in institutional setting, that is, the police station indicated by the adverbial '^here' (zheli 这里), based on the rationale that people do not chat or do small talk at the police station, a place where people are supposed to resolve disputes. The deconstruction of P's temporarily selfconstructed acquaintance identity might reveal A's eagerness to solve the conflict at hand.

\subsubsection{By negating the social rightness of the identities}

The data also show that the disputants might deconstruct the police officers' selfconstructed identity via negating its social rightness on the basis of a rationale drawn from certain social norms, especially those prescribed by the institution. Consider Extract (3):

Extract 3 .

(Context: A conflict between two brothers: the elder brother A quarrels with the younger brother B for some land problem, and B called the police for help.)

O1 P: 别吵了, 弟兄两个有什么不好讲的?

O2 A：弟兄俩、还弟兄俩\&

O3 P：哎, 你少讲两句, 你要这样讲, 这个态度, 我是他也不愿意给你!

O4 B：你看看他那样子, 我跟你讲, 绝对没人服他!

05 A：没人服，管！照！你们领导都回去吧!

06 P：哎呀，你这态度不好！你\&

O7 B：我们家庭的事情，你们处理不好，你们不要处理，等、等明天闹出 人命了, 搞出刑事案件了, 你们再来搞!

o8 P: (@@)不要这样讲!

((省略))

o1 P: Don't quarrel any more! There is nothing that can't be solved between brothers! 
O2 A: Brothers? Is he my brother?

03 P: Ai, you talk less! If you keep talking like this, with this kind of attitude, then if I were him, I wouldn't agree to let you use the land either.

o4 B: Look at him and the way he behaves! Let me tell you, nobody will consider him as appropriate!

05 A: Ok! Nobody will consider me as appropriate! Ok! Ok! You officers go back!

o6 P: Aiya! Your attitude is not good! You \&

o7 A: This is our family issue, and you can't handle well. You shouldn't handle it now, wait, wait till somebody is dead one day, then it will become a criminal case, then you come back and handle it!

o8 P: (@@)Don't say that!

$(($ Omitted) $)$

In this extract, in order to help the two brothers calm down and reconcile with each other, $\mathrm{P}$ tried to construct an identity of 'scolding brother' by means of a conditional clause with the subjunctive mood to criticize A's bad attitude (03, 06). But A was very angry about the fact that many neighbors thought he had done something wrong. Here, A deconstructed P' s self-constructed 'scolding brother' identity by overtly addressing him with an institutional identity label 'You officers' (nimen lingdao 你们领导) (05) and negating the social rightness of the scolding brother identity by emphasizing the fact that the quarrel between brothers was a 'family issue' (jiating de shiqing 家庭的事情) rather than a 'criminal case' (xingshi anjian 刑事案件) and thus was beyond police officer's duty (07). In this way, A positioned $\mathrm{P}$ back to his institutional identity as a police officer, hence deconstructing the latter's self-constructed identity as a scolding brother.

4.2 Police officers' deconstruction of identities assigned by the disputants

Talk in ostensibly institutional settings can sometimes be "noninstitutional", and speakers may move in and out of institutional talk and ordinary talk (Benwell and Stokoe 2006, 96-97). Data of this study show that while the disputants tended to assign institutional identities to police officers, the latter might deconstruct such institutional identities assigned to them by deliberately adopting non-institutional identities. Specifically, the police officers might deconstruct their other-assigned institutional identities by negating the institutional goal, relationship or identity and claiming a non-institutional identity. 


\subsubsection{By negating the validity of the other-assigned institutional identity and clarifying a non-institutional identity or communicative goal}

What is found interesting in our data is that, in mediation discourse, which is institutional in nature, police officers often deconstructed their institutional identities assigned by the disputants via negating the validity of the institutional identity and claiming a non-institutional identity or clarifying a non-institutional communicative goal. Consider Extract (4) (Due to the word limit of the journal, some turns between turns 13 to 14 that do not affect the analysis of this article are omitted here.):

Extract 4 .

(Context: A is a resident in one community, who falls into dispute with the property management company due to some housing renovation issues. $\mathrm{B}$ is the manager of the property management company. $\mathrm{P}$ is the police officer who conducts mediation for them.)

01 A： 我的天，你现在怎么给警察又喊来做什么? 他们能给我解决?

O2 B：你问问我们这些师傅们，我们只是让他们来做个见证。

O3 A： 那你要是给警察喊来，那你也把你们领导喊来！

O4 P： 老顾，你消消气，你消消气\&

$05 \mathrm{~A}$ ：我老婆那天摔了打电话给你们派出所，你们为什么不给我做见 证?

06 P：听我说\&

o7 A：为什么官官相护给他们做见证?

08 P：怎么、官官相护怎么讲？你这个官官相护从哪来的？我的烸来 $(($ 天 啊))! 我什么话都没讲呢就官官相护了吗?

09 A：(@@)那你讲。

$10 \mathrm{P}$ ：你说你哪天报警他们没去，你可以打 110 ，有督查，你可以投诉\&

$11 \mathrm{~A}$ ：我投诉有X用啊！我不需要投诉! 我现在\&

12 P：讲话就好好说，听我跟你说，听我说，有话好好说，不要带口头 ((脏话))好吧?

$13 \mathrm{~A}$ ：我就是这个X样! 我就是这个X样! 我们小老百姓! ... $4 \mathrm{~s}$

14 P: 我们可管讲话了?

$15 \mathrm{~A}: \quad \ldots 3 \mathrm{~s}$

$16 \mathrm{P}$ ：老顾，你听我说，你听我给你讲，我们现在来了，不是针对你也 不是针对她，而是看看在中间怎么给你们协调协调，把这个事解决 掉，你老是纠结之前的事有什么意义呢?

$17 \mathrm{~A}$ :

o1 A: My Goodness! Now what do you want to do by calling the police to come here? Can they solve my problem? 
02 B: You can ask these Shifu, we just want them to be witnesses here.

03 A: Now that you call the police to come here, you should also call your boss to come here!

04 P: Lao Gu, don't get so angry, calm down\&

05 A: That day my wife fell and called you, the police station, and why didn't you come to be a witness for me?

o6 P: listen to me\&

07 A: Why now you officials shield each other and come to be a witness for them? o8 P: How come... where does the saying that "officials shield each other" come from? Aiya! My Goodness! I didn't say a word! How come the "officials shield each other"?

o9A: (@@) ok then, you speak now.

10 P: You said that you called the police and they didn't come then you can call 110 to make a complaint to the inspector\&

11 A: What's the fucking point to make a complaint? I don't need to complain! I now \&

$12 \mathrm{P}$ : When you talk with others, talk in a polite way! listen to me, listen to me! When you have something to say, say it in a polite way. Don't use dirty words, ok?

$13 \mathrm{~A}$ : I just talk in this fucking way! I just talk in this fucking way! We little people! ... 4s

14 P: Can we speak now?

$15 \mathrm{~A}: \quad \ldots 3 \mathrm{~s}$

16 P: Lao $G u$, listen to me, listen to what I am going to tell you, that is, now we come here not to be against you or her, rather we are here to see if we can be in the middle of you two and help solve the problem for you. There is no point in feeling upset with the causes of the problem, right?

$17 \mathrm{~A}:$

((omitted))

In this extract, A was very angry because the manager B called the police, which seemed to imply that A had done something wrong. So with anger and rude manners, A questioned P's neutrality and positioned him in an unjust officer identity by stating an incident in which police officers did not respond to his call (05, o7) and overtly addressing the police with the identity label "you officials"(nimen guan 你们官) (07) and himself “We little people" (Women xiao laobaixing 我们小 老百姓) (13), thus positioning P in his institutional identity and their relationship in unequal power relationship. Then $\mathrm{P}$ deconstructed this imposed, unwanted institutional identity by negating the truth validity (Habermas 1976) of the speech act $\mathrm{A}$ used to construct this identity, that is, $\mathrm{P}$ 'didn't say a word' (shenme hua dou mei jiang 什么话都没讲) (o8), so he did nothing, let alone anything wrong that 
could make him an unjust officer who took the property management company's side and shielded the manager. In other words, the accusation of $\mathrm{P}$ as being an unjust officer was countered by means of negating its truth validity and further clarifying his communicative goal, which was not to be against anyone but to help A solve the problem (16). At the same time by addressing A, whom P met for the first time, with the adjective Lao 老 (meaning 'old' literally in Chinese, and when used in an address form ending with a family name, implying that the addresser and addressee know each other for a long time) plus A's family name $G u$ 顾 (o4, 16), an address structure used commonly among old friends or acquaintances in Chinese to indicate equal power and solidarity (Ma 2011, 43), $\mathrm{P}$ attempted to construct the identity of an acquaintance-like helper, which was verified by A's final silence $(17)$ after so many confrontational responses $(05,07,11,13)$ to the previous turns of $\mathrm{P}$.

\subsubsection{By negating the institutional relationship and claiming a non- institutional relationship}

We also found in the data that police officers in mediation interaction often deconstructed their other-assigned institutional identity via negating the institutional relationship implied by the identity and at the same time claiming a non-institutional relationship, because the latter could establish a much closer interpersonal relationship between the police and disputants. Consider Extract (5):

\section{Extract 5 .}

(Context: there is typhoon alert, and A is a homeless old man who lives in the low-lying area under a bridge and refuses to leave. One passer-by reports it to the police for the safety of the old man.)

o1 P：大爷，有台风来了，您不能住在这里了，很危险的。跟我们走吧， 先跟我们回派出所，我们把您送到安全地方。

O2 A：我不去，我又^没犯^法!

03 P：派出所不是只有坏人可以去，^好人也可以去的。

04 A：我不去，我想干什么就干什么!

05 P: 大爷, 我们是来帮助你的, 你吃晚饭了吗?

06 A：没有。

07 P: 那我们一会请你吃饭哦。

o8 A: (@@)

o1 P: Uncle, a typhoon is coming, so you can't stay here any more, because it's too dangerous. Go with us to the police station first, and later we will send you to some place safe, ok? 
O2 A: No, I won't go! $\underline{I \wedge \text { haven't committed any } \wedge \text { crime! }}$

03 P: Not only the bad guys go to police station, so do the ${ }^{\wedge}$ good ones!

4 A: I won't go! I can do whatever I want to do!

05 P: Uncle, we come here to help you. And have you had your dinner?

o6 A: No.

o7 P: Ok, then, later we will buy you dinner, ok?

o8 A: (@@)

In this extract, $\mathrm{P}$ constructed the identity of a younger family member by addressing A Daye 大爷 ('Uncle') and nin 您 ('you') (o1), a second-person honorific, but A implicitly negated this identity by stating the fact that " $I \wedge$ haven't committed any ^ crime (Wo you mei fan fa 我又没犯法) (02), thus positioning them in an institutionally prescribed police-suspect relationship. $\mathrm{P}$ then deconstructed this imposed identity by stating the fact that 'good ones' can also go to the police station (03), thus proposing a new police-citizen/helping-helped relationship with the use of identity label haoren 好人 ('good ones') in a marked pitch. Being refused again, P further addressed A again with the kinship term Daye 大爷 ('Uncle'), emphasizing overtly a non-institutional communicative goal, that is, "to help you" (lai bangzhu ni 来帮助你) (05), and offers A dinner (qing ni chi fan o 请你吃饭 哦) (07) to show their care for him like real family members, with a view to having the family member relationship constructed. The police officer's attempt was successful because the constructed identity was verified by A, as shown by the latter's laughter (08).

While there were other situations of identity deconstruction, the illustration above suffices to demonstrate the complexity of the conversational practice in the police mediation setting. However, it is also worth mentioning that, according to our observation by one-month participation in the police mediation discourse, of the two types of identity deconstruction initiated by either disputants or police officers themselves, the former one invariably concerned the disputants' deconstruction of the non-institutional identities constructed by the police officers, while the latter more often than not concerned the police officers' deconstruction of the institutional identities assigned to them by the disputants. The next section will discuss in more detail about the various contextual factors that may have given rise to this phenomenon, including both the immediate context and the wider social context of interaction/ communication. 


\section{Discussion}

What caused the afore-mentioned identity deconstruction phenomena in Chinese police mediation discourse? To be more specific, why, on the one hand, did the disputants try to deconstruct the non-institutional identities constructed by the police officers, whereas, on the other hand, did the police officers try to deconstruct the institutional identities assigned to them by the disputants? The root cause might be found in the answer to another question: what caused the Chinese police officers involved to construct the various non-institutional identities besides their institutionally prescribed identities?

Our answer to the last question is that the police officers' deconstruction of the institutional identities assigned to them by the disputants as well as construction of non-institutional identities (leading to deconstruction by the disputants) was motivated by their communicative need to deal with the identity dilemma or identity struggle (Zhao 2017) they were in. According to the Law of the People's Republic of China on Public Security Administration in 2006, in addition to maintaining the traditional governance relationship with the citizens, Chinese police officer has the duty of developing a new type of helping-helped and servingserved police-citizen relationship in their civil conflict mediation work. This new duty gives rise to an identity dilemma for police officers in mediation context. Specifically, police officers are supposed to talk not only with the default institutional identities such as the interpreter and defender of the law based on the more powerful police-citizen (and sometimes even police-suspect relationship), but also with non-institutional identities such as helper(s), as we found in our data. This may explain why the police officers in our study constructed an array of deviational identities such as acquaintances, friends, and family members. The difficulty with maintaining this two-part identification - (1) being a powerful, serious and just administrator and (2) being a friendly, considerate and close helper - is that "the communicative actions that ensure that one is attending to the first part of the ideal are just the communicative actions that endanger the second part of the ideal" (Tracy 2002, 35). Therefore, the police officers' deconstruction of the institutional identities assigned to them was exactly a reflection of the conflict caused by this identity dilemma of theirs in the course of the mediation.

However, since the disputants might not well understand the identity dilemma the police officers faced, they opted to deconstruct the non-institutional identities constructed by the police officers. After all, their primary communicative need was to solve the conflict at hand, and what justified their deconstruction was their expectation for the police officers to adopt their institutional identity. The disputants' expectation goes well with Chen's (2018) Maxim of Identity that under normal circumstances, speakers tend to choose the default identities that 
match the present communicative context on the basis of specific identity schema appropriate to the context. According to Richards (2006), "social settings and institutions impose many types of principles and rules on the ways in which certain types of linguistic acts can be performed, or who has the right to perform them" (Verschueren 2000, 91). When the speaker's constructed identity is different from the hearer's identity expectation based on specific contexts, then conflict in the form of identity deconstruction may occur. Just as what Garcés-Conejos Blitvich $(2018,121)$ says, conflict is intimately linked to identity construction, and what makes it so is the reaction it gets. Therefore, default identities are institutionally prescribed and interpersonally expected while deviant identities are marked. This explains why in police mediation the deviant or non-institutional identities constructed by the police officers were sometimes deconstructed by disputants due to their lack of "fit" for the institutional setting, default relationship or identity type.

Conflict may not be resolved until relational goals are managed. The police officers' deconstruction of other-assigned identities could be interpreted as one move to cope with the above-mentioned identity conflict. Disagreements are not always face-threatening or relationship-hurting. Some strong disagreement on the surface may improve relationship while some weak disagreement may in fact threaten relationship (Chan et al. 2018). In this study, as shown by the analysis in Section 4.1, other-initiated deconstruction of the police officers' selfconstructed identities, mostly deviational identities such as acquaintances or family members, by re-positioning them in their institutional identities, separates the police-citizen relationship further in terms of relational distance, hence threatening the police-citizen relational alignment. However, it is shown from the analysis in Section 4.2 that the police officers' deconstruction of their other-assigned identities, while also a kind of conflictive disagreement in nature, might exert positive effects on the police-citizen relationship, although they might slow down the process of problem solving. Thus, the police officers' deconstruction of the institutional identities assigned to them by claiming a non-institutional goal, identity or relationship in fact serves to get rid of misunderstandings and shorten the interpersonal distance between the police and disputants. In other words, their deconstruction effort might be interpreted as a kind of relation repair strategy, thus improving the police-citizen relationship and achieving alignment with them. This interpretation is of crucial importance because it might bring us a different understanding from the conclusion drawn by some previous studies on identity negotiation, namely, while the verification of valued identities can lead to affiliation, alignment and face support, "challenge, however, can cause disaffiliation", and "an evaluation of face threat is made when a speaker perceives that an identity they are claiming is not ascribed to them by their partner" (Tracy 2008; 
Haugh 2009; Garcés-Conejos Blitvich et al. 2013; Donaghue 2015, 195). Thus, we would argue that not all identity challenges threaten interpersonal relationship, and that whether identity deconstruction enhances or threatens interpersonal relationship depends on what type of identity is deconstructed and what reaction it incurs from the target communicators.

\section{Conclusion}

This paper reports on a study of identity deconstruction that is distinctive in several ways. First, while existing research on identity deconstruction focuses on the different linguistic means to achieve identity deconstruction or on the negation of attributes of professional identity such as professional knowledge, ethics or competence, this study explores why a self- or other-constructed identity can be deconstructed. It was found that the contextual inappropriateness of a constructed or assigned identity and communicator's communicative goal will incur identity deconstruction. Second, while previous research almost exclusively focuses on professional or institutional identity deconstruction as a way to construct identity, this study focuses specifically on the various situations in which identities are deconstructed. Thirdly, while a lot of previous studies of identity focus on professional or institutional identity construction in institutional settings, this study pays close attention to the strategic use of non-institutional identity in institutional setting.

Based on the qualitative analysis of the identity deconstruction process with data collected from Chinese police mediation discourse, this study yielded the following major findings:

A. The identity deconstruction in Chinese police mediation discourse constitutes a complex interactional practice, as it occurs in varied situations and can be initiated by different participants for various communicative goals and based on various contextual rationale, which provides "the argumentative link between metapragmatic behaviour and the social order" (Davies 2018, 121).

B. The police officers' deconstruction of institutional identity assigned by the disputants is rooted in the former's identity dilemma arising from social changes regarding police work in China. The deconstruction process initiated by the disputants exerts negative effects on the police-citizen relationship for it separates the police-citizen interpersonal distance further while the identity deconstruction initiated by police officers themselves kind of serves as a repair strategy and brings the police-citizen interpersonal distance closer, thus achieving alignment between the police and citizens. 
While these findings may contribute to our understanding of police mediation and enrich current pragmatic approach to identity, this study is limited in two important ways: First, as this study was the first attempt to explore the identity deconstruction of police mediation discourse in China, there was therefore a lack of existing reviews to help us analyze the deconstruction process and influencing factors, both broadly and more in-depth. Consequently, our findings and discussion should be further ascertained by future studies about identity negotiation in Chinese police mediation discourse. Second, as this study used a qualitative research method on a small scale, the credibility of the current analysis might not be adequately high. In the future, the findings of this study can be bolstered by both quantitative and qualitative studies.

\section{Funding}

This article is supported by the project (18YJC740015) on the identity construction of Chinese police officers in civil conflict mediation at police stations funded by Ministry of Education of the People's Republic of China.

\section{Acknowledgements}

This article, now revised under supervision of Xinren Chen, received the Best Student Submission Award for the 16th International Pragmatics Conference, Hong Kong, 9-14 June 2019. Its completion has benefited from the constructive suggestions of Professor Winnie Cheng and other reviewers at the 16 th IPrA Conference.

\section{References}

Antaki, Charles, and Sue Widdicombe. 1998. “Identity as an Achievement and as a Tool.” In Identities in Talk. ed. by Charles Antaki, and Sue Widdicombe, 1-15. London: Sage.

Benwell, Bethan, and Elizabeth Stokoe. 2006. Discourse and Identity. Edinburgh UK: Edinburgh University Press.

Bercal, Thomas E. 1970. "Calls for Police Assistance: Consumer Demands for Governmental Service." American Behavioral Sciences 13 (5): 681-690.

https://doi.org/10.1177/000276427001300504

Black, Donald. 1980. The Manners and Customs of the Police. New York: Academic Press. Bucholtz, Mary, and Kira Hall. 2005. "Identity and Interaction: A Socio-cultural Linguistic Approach.” Discourse Studies 7 (4-5): 585-614. https://doi.org/10.1177/1461445605054407 Buerger, Michael E., Anthony J. Petrosino, and Carolyn Petrosino. 1999. "Extending the Police Role: Implications of Police Mediation as a Problem- Solving Tool.” Police Quarterly 2 (2): 125-149. https://doi.org/10.1177/109861119900200201 
Chan, Angela, Stephanie Schnurr, and Olga Zayts. 2018. "Exploring Face, Identity and Relationship Management in Disagreements in Business Meetings in Hong Kong." Journal of Politeness Research 14 (2): 233-260. https://doi.org/10.1515/pr-2015-0036

Chen, Rong, and Xinren Chen. 2020. “Introduction." East Asian Pragmatics 5 (1):1-8. https://doi.org/10.1558/eap.40374

Chen, Xinren. 2013. “语用身份：动态选择与话语建构 [Pragmatic Identity: Dynamic Choice and Discursive Construction]." Foreign Languages Research 4: 27-112.

Chen, Xinren. 2014. “语用学视角下的身份研究一关键问题与主要路径 [Current Research on Identity from the Pragmatic Perspective: Key Issues and Main Approaches].” Modern Foreign Languages 37 (5): 702-710.

Chen, Xinren. 2018. Pragmatic Identity: How to Do Things with Words of Identity. Beijing: Beijing Normal University Press.

Chen, Xinren. 2020. "Identity Work and Politeness Evaluation." Journal of PLA University of Foreign Languages 43 (2): 1-10.

Cooper, Christopher. 2001. "Mediation in Black and White: Mediation Center-Police Partnerships - A Dignified Police Response." Mediation Quarterly 18 (3): 281-295. https://doi.org/10.1002/crq.3890180307

Davies, Bethan L. 2018. "Evaluating Evaluations: What Different Types of Metapragmatic Behaviour Can Tell Us About Participants' Understandings of the Moral Order." Journal of Politeness Research 14 (1): 121-151. https://doi.org/10.1515/pr-2017-0037

D'Cruz, Carolyn. 2008. Identity Politics in Deconstruction: Calculating with the Incalculable. England, Hampshire: Ashgate Publishing Limited.

Deaux, Kay, and Kathleen A. Ethier. 1998. “Negotiating Social Identity." In Prejudice: The Target's Perspective, ed. by Janet K. Swim, and Charles Stangor, 301-323. San Diego: Academic Press. https://doi.org/10.1016/B978-012679130-3/50049-1

De Fina, Anna, Deborah Schiffrin, and Michael Bamberg. 2006. Discourse and Identity. Cambridge: Cambridge University Press. https://doi.org/10.1017/CBO9780511584459 Deng, Yiheng, Kaibin Xu, Xiaoqiu Fu, and Sang Ma. 2013. "Mediating Conflict on TV: A Discourse Analysis of the Gold Medal Mediation Episodes." China Media Research 9 (4): 5-14.

Dobs, Abby Mueller. 2014. "Identities in Conflict: Examining the Co-construction of Impoliteness and Identity in Classroom Interaction." Journal of Language Aggression and Conflict 2 (1): 36-73. https://doi.org/10.1075/jlac.2.1.02dob

Donaghue, Helen. 2015. The Construction and Negotiation of Identity and Face in Post Observation Feedback. PhD dissertation, Aston University, UK.

Donaghue, Helen. 2018. "Relational Work and Identity Negotiation in Critical Post Observation Teacher Feedback." Journal of Pragmatics 135: 101-116. https://doi.org/10.1016/j.pragma.2018.08.002

Du Bois, John W., Stephan Schuetze-Coburn, Susanna Cumming, and Danae Paolino. 1993. "Outline of Discourse Transcription." In Talking Data: Transcription and Coding in Discourse Research, ed. by Jane A. Edwards, and Martin D. Lampert. 45-89. Hillsdale, NJ: Lawrence Erlbaum.

Gamson, Joshua. 1995. "Must Identity Movements Self-Destruct? A Queer Dilemma." Social Problems 42 (3): 390-407. https://doi.org/10.2307/3096854

Gao, Wenying. 2008. “警察调解制度研究 [Study on the Mechanism of Police Mediation].” Journal of Chinese People's Public Security University 134 (4): 127-134. 
Garcés-Conejos Blitvich, Pilar, Patricia Bou-Franch, and Nuria Lorenzo-Dus. 2013. "Identity and Impoliteness: The Expert in the Talent Show Idol." Journal of Politeness Research 9: 97-121. https://doi.org/10.1515/pr-2013-0005

Garcés-Conejos Blitvich, Pilar. 2018. "Globalization, Transnational Identities, and Conflict Talk: The Superdiversity and Complexity of the Latino Identity." Journal of Pragmatics 134: 120-133. https://doi.org/10.1016/j.pragma.2018.02.001

Garcia, Angela Cora. 2012. "Advice-giving and Disputant Empowerment in Divorce Mediation Sessions." Language and Dialogues 2 (3): 398-426. https://doi.org/10.1075/ld.2.3.05gar

Habermas, Jürgen. 1976. “What Is Universal Pragmatics?” In On the Pragmatics of Communication, ed. by Maeve Cooke, 21-103. Cambridge, Massachusetts: The MIT Press.

Haugh, Michael. 2009. "Face and Interaction." In Face, Communication and Social Interaction, ed. by Bargiela-Chiappini Francesca, and Michael Haugh, 1-16. London: Equinox.

Heisterkamp, Brian L. 2006. "Conversational Displays of Mediator Neutrality in a Courtbased Program." Journal of Pragmatics 38: 2051-2064. https://doi.org/10.1016/j.pragma.2006.03.005

Jacobs, Scott. 2002. "Maintaining Neutrality in Dispute Mediation: Managing Disagreement While Managing Not to Disagree." Journal of Pragmatics 34: 1403-1426. https://doi.org/10.1016/So378-2166(02)00071-1

Jiang, Ting. 2016. “态度系统视阈下仲裁员调解话语的人际意义分析 [On Interpersonal Meanings in Arbitrators' Mediation Discourse: A Perspective from Attitude System].” Modern Foreign Languages 39 (2): 188-197.

Jin, Ying. 2018. "Small Talk in Medical Conversations: Data from China." Journal of Pragmatics, 134: 31-44. https://doi.org/10.1016/j.pragma.2018.06.011

Ke, Xianbing. 2017. “我(不)想X/Y’ 法庭调解话语策略表达机制研究 [An Empirical Study of Court-related Strategical Mediated Discourse Mechanism: A Case Study of 'I Don't Want X/Y']." Journal of Zhejiang International Studies University 2: 3-11.

Klooster, Susan A. van 'T., Marjolein B.A. van Asselt, and Sjaak P. Koenis. 2002. "Beyond the Essential Contestation: Construction and Deconstruction of Regional Identity." Ethics, Place \& Environment 5 (2): 109-121. https://doi.org/10.1080/1366879022000020185

Li, Cheng-Tuan, and Yong-Ping Ran. 2016. "Self-professional Identity Construction Through Other-identity Deconstruction in Chinese Televised Debating Discourse." Journal of Pragmatics 94: 47-63. https://doi.org/10.1016/j.pragma.2016.01.001

Li, Cheng-Tuan, Yong-Ping Ran, and Daniel Kádár. 2018. "Constructing Self-expert Identity via Other-identity Negation in Chinese Televised Debating Discourse.” Text \& Talk 38 (4): 435-455. https://doi.org/10.1515/text-2018-0009

Li, Xiangyun, and Chengfang Song. 2014. “离婚调解话语中男女权力失衡问题研究 [An Analysis of the Power Imbalance Between Men and Women in Divorce Mediation Discourse]." Journal of Ocean University of China 4:123-128.

Locher, Miriam A. 2011. "Situated Impoliteness: The Interface Between Relational Work and Identity Construction.” In Situated Politeness, ed. by Bethan L. Davies, Michael Haugh, and Andrew John Merrison, 187-208. London: Bloomsbury.

Locher, Miriam A., Brook Bolander, and Nicole Höhn. 2015. "Introducing Relational Work in Facebook and Discussion Boards." Pragmatics 25 (1): 1-21. https://doi.org/10.1075/prag.25.1.01loc 
Malinowski, Bronislaw. 1923. “The Problem of Meaning in Primitive Languages.” In The Meaning of Meaning, ed. by Charles Kay Ogden, and Ivor Armstrong Richards, 296-336. London: Routledge \& Kegan Paul.

Ma, Peipei. 2011. “汉语称呼语中“老”字的权势与等同关系探析 [The Power and Solidarity of the Word "Lao" in Chinese Address Terms]." Journal of Hebei North University 27 (2): $42-44$.

Marinova, Diana. 2007. Neutrality in Mediation Hearing: Managing the Mediation Process without Bias. PhD dissertation, Georgetown University, Washington, D. C.

Morasso, Sara Greco. 2011. Argumentation in Dispute Mediation: A Reasonable Way to Handle Conflict. Amsterdam: John Benjamins. https://doi.org/10.1075/aic.3

Mullany, Louise. 2008. "Impoliteness, Power and Gender Identity in the Professional Workplace." In Impoliteness in Language, ed. by Derek Bousfield, and Miriam A. Locher, 231-251. The Hague: Mouton de Gruyter.

Poovey, Mary. 1988. "Feminism and Deconstruction." Feminist Studies 14 (1): 51-65. https://doi.org/10.2307/3177998

Ran, Yongping, and Linsen Zhao. 2018. "Building Mutual Affection-based Face in Conflict Mediation: A Chinese Relationship Management Model.” Journal of Pragmatics 129: 185-198. https://doi.org/10.1016/j.pragma.2018.01.013

Richards, Keith. 2006. “'Being the Teacher': Identity and Classroom Conversation.” Applied Linguistics 27: 51-77. https://doi.org/10.1093/applin/amio41

Sacks, Harvey. 1972. "On the Analyzability of Stories by Children.” In Directions in Sociolinguistics: The Ethnography of Communication, ed. by. John J. Gumperz, and Dell Hymes, 325-345. New York: Blackwell.

Schnurr, Stephanie, and Olga Zayts. 2011. "Be(com)ing a Leader: A Case Study of Coconstructing Professional Identities at Work." In Constructing Identities at Work, ed. by Jo Angouri, and Meredith Marra, 40-60. Basingstoke: Palgrave Macmillan. https://doi.org/10.1057/9780230360051_3

Shen, Zhengwei. 2015. “民警在治安调解中的效力分析 [Analysis on the Effectiveness of Police in Public Security Mediation]." Journal of Anhui Vocational College of Police Officers 81 (6): 51-54.

Stokoe, Elizabeth, and Rein Sikveland. 2016. "Formulating Solutions in Mediation." Journal of Pragmatics 105: 101-113. https://doi.org/10.1016/j.pragma.2016.08.006

Tong, Shan. 2013. A Conversation-analytic Study of People's Mediating Utterances. PhD dissertation, East China Normal University, China.

Tracy, Karen. 2002. Everyday Talk: Building and Reflecting Identities. New York: Guilford Press.

Tracy, Karen. 2008. “'Reasonable Hostility’: Situation-appropriate Face-attack.” Journal of Politeness Research 4: 169-191. https://doi.org/10.1515/JPLR.2008.009

van Dijk, Teun A. 2009. Society and Discourse: How Social Contexts Influence Text and Talk. New York: Cambridge University Press. https://doi.org/10.1017/CBO9780511575273

Verschueren, Jef. 2000. Understanding Pragmatics. Beijing: Foreign Language Teaching and Research Press.

Volpe, Maria R. 2014. “Police and Mediation: Natural, Unimaginable or Both.” In Moving Toward a Just Peace: The Mediation Continuum, ed. by Jan Marie Fritz, 91-105. New York, London: Springer Dordrecht Heidelberg. https://doi.org/10.1007/978-94-007-2885-1_6 
Wagner, Wolfgang, Peter Holtz, and Yoshihisa Kashima. 2009. "Construction and Deconstruction of Essence in Representating Social Groups: Identity Projects, Stereotyping, and Racism." Journal for the Theory of Social Behaviour 39 (3): 363-383. https://doi.org/10.1111/j.1468-5914.2009.00408.x

Wall, James, and Michael Blum. 1991. "Community Mediation in the People's Republic of China." Journal of Conflict Resolution 35 (1): 3-20. https://doi.org/10.1177/0022002791035001001

Wang, Ting. 2014. “完善我国警察调解制度的几点建议 [On Police Mediation in China].” Journal of China Maritime Police Academy 12 (3): 69-75.

Wen, Xu. 2018. “言语交际中称谓的认知语用问题 [Cognitive-Pragmatic Aspects of Vocatives in Verbal Communication]." Journal of Zhejiang International Studies University 2: 35-40.

$\mathrm{Xu}$, Youping. 2019. "Scolding 'Brothers' and Caring 'Friends': Discursive Construction of the Identity of China Media Research.” International Journal for the Semiotics of Law 32 (1): 135-153. https://doi.org/10.1007/s11196-018-9574-9

Yuan, Zhoumin. 2011. An Empirical Study of Medical Consultants' Pragmatic Identity Construction from the Adaptationist Perspective. PhD dissertation, Nanjing University, China.

Zhao, Lizhi. 2017. “中国当代警察身份认同问题探析一体制、文化、社会环境视角 [Identity Struggle of Contemporary Chinese Policemen: from the Perspective of System, Culture and Social Environment]." Journal of Sichuan Police College 29 (2): 7-16. 


\section{Appendix 1}

Table a1. Transcription conventions

\section{Transcription conventions}

Speech

Transitional continuity

Final

Continuing

Appeal (seeking a validating response from listener)

Speakers

Speech overlap

Interruption

Accents and lengthening

Primary accent

(prominent pitch movement carrying intonation meaning)

Lengthening

\section{Pause}

Long pause

Vocal noises

Laughter

@

Transcriber's perspective

Researcher's comment

\section{Address for correspondence}

Wenjing Feng

English Department, School of Foreign Studies

Nanjing University

163 Xianlin Dadao

Nanjing 210023

China

158094441@qq.com 


\section{Biographical notes}

Wenjing Feng is a PhD student in Nanjing University. Her research interests include discourse analysis, pragmatics and sociolinguistics in Chinese and English. She has performed ethnographic study on Chinese police mediation discourse, and right now is doing a project on identity (de)construction of Chinese police officers in civil conflict mediation discourse funded by Ministry of Education of the PRC. She is author of Universal Pragmatics of Habermas: Theories and Application (2017).

(iD https://orcid.org/000o-0002-3747-8468

Prof. Xinren Chen graduated from Guangdong University of Foreign Studies in 1999 with a $\mathrm{PhD}$ degree in linguistics and applied linguistics. He is director of Institute of Foreign Linguistics at Nanjing University. His major research interests include pragmatics, L2 pragmatic acquisition, and language policy and language planning. He is author of The Pragmatics of Interactional Overinformativeness (2004), Critical Pragmatic Studies of Public Discourse (2013/ 2020), and Pragmatic Identity: How to Do Things with Words of Identity (2018), and (co-)editor of Politeness Theories and Foreign Language Learning (2013), Pragmatics and Foreign Language Teaching (2013), Linguistic Memetics: Theory and Application (2014), and Politeness Phenomena Across Chinese Genres (2017).

\section{Publication history}

Date received: 25 September 2019

Date accepted: 12 November 2019

Published online: 3 June 2020 